\title{
Tactical Soundwalking in the City: A Feminist Turn from Eye to Ear
}

\author{
Stephanie Loveless \\ Department of the Arts \\ Rensselaer Polytechnic Institute \\ 110 8th Street, Troy, NY 12180 \\ lovels3@rpi.edu
}

\begin{abstract}
The histories of walking in art are both male-dominated and visually oriented. This is most clearly expressed in the 19th century figure of the "flâneur." Building on the history of both the flâneur and Guy Debord's psychogeographic "dérive," Michel de Certeau's "Walking in the City," published in 1980, suggests walking as a tactical act of resistance to the alienation of the modern city. While de Certeau begins his essay with a critique of visuality, or the scopic drive, he misses a crucial opportunity to move from eye to ear. In alliance with the sonic philosophy of Salomé Voegelin, this paper argues for listening as a mode that, counter to the objectifying uses to which visuality has culturally been put, offers a mode of engaging with the world that is relational, ecological, and feminist in orientation. Through a discussion of the practices of soundwalking and Deep Listening, and analysis of soundwalking projects by Suzanne Thorpe, Viv Corringham, and Amanda Gutierrez, a new story emerges about listening in public space as a tactical act.
\end{abstract}

Walking. Soundwalking. Deep Listening. Feminist. Urban.

\section{FLÂNEUR I FLÂNEUSE}

Let us begin with the flâneuse: The term flâneuse is a reappropriation of word flâneur, a word that's gendered as male not only grammatically, but conceptually. A popular literary figure of 19thcentury France, the flâneur is the quintessential urban wanderer, a dissociated observer of modern society. The flâneur is also the archetypal figure of a history of walking in art and literature that has generally been oriented around the male subject from Charles Beaudelaire to Richard Long to Vito Acconci. In response, recent feminist histories have turned to the walking practices of writers like Virginia Woolf and George Sand to uncover how female subjects have historically navigated public spaces differently from their male counterparts. These narratives reveal how a female-identified walker - a flâneuse -suggests alternate ways of moving through public space.

Lauren Elkin, in her publication on this history of the flâneuse, quotes an anonymously-authored pamphlet from 1806 that defines the flâneur as "a man-about-town who comes from sufficient wealth to be able to have the time to wander the city at will, taking in the urban spectacle" (Elkin, 2017a, p. 3). But, as Elkin muses in an interview on her treatise: ...if the flâneur represents an emotionally detached man out on the street taking it all in, maybe if that's not possible for a woman, she can instead choose to be very engaged. For women, perhaps being in the city and walking is a form of extreme un-detachment...bound up in everything that's happening in your environment. (Elkin, 2017b)

1.2 As he walks, he looks. As she walks, she listens

How does the flâneur "take in" his environment? Honoré de Balzac (1886) described flânerie as "the gastronomy of the eye"; Victor Fournel (1867) described the "art of flânerie" as a moving picture ("un daguerréotype mobile") of city life. In other words, as the historically male figure of the flâneur walks, he looks. In this paper, I counter this figure with one that I find much more generative: the female flâneuse who walks the city, and as she walks, listens.

I articulate the necessity of this move to listening, and its relationship to feminist practice, by contrasting the work of French philosopher Michel de Certeau with the work of Pauline Oliveros (founder of the philosophy and practice of Deep Listening) and Hildegard Westerkamp (innovator of soundwalking). I close with an examination of soundwalking projects by three contemporary 
artists (Suzanne Thorpe, Viv Corringham and Amanda Gutierrez) that tease out an alliance between feminism, walking practices, and listening, in order to ask, what is feminist soundwalking, or flâneuserie sonore?

The feminism at stake here is, of course, not simply about women - though women are, indeed, my main interlocutors. Rather, I understand feminism as a political orientation able to be practiced by any sex or gender identity, that seeks to undo the structural power imbalances of sexism in intersection with racism, heterosexism, and class oppression. Ultimately, my claim is that feminist practice has the power to counter hierarchy and oppression through the strategies of responsive collaboration that are deployed by the artists I discuss in this paper.

\section{WALKING IN THE CITY}

Michel de Certeau's influential The $P$ ractice of Everyday Life, published in 1980, explores creative reappropriations of everyday activities for revolutionary ends. In the seventh chapter, turning to the everyday practice of walking, de Certeau builds on Guy Debord's psychogeographic concept of the derive, which is itself grafted on top of the idea of the flâneur. A dérive is an unplanned "drift" through a city in which one allows themselves to be drawn by the flows of attractions exerted by different locations (Debord, 2014). In "Walking in the City," de Certeau proposes his own methods of walking as a tactic of creative resistance to the systems of repression that, for him, are structurally built into our urban environments (1988).

As I have argued, the white, male flâneur not only walks, but looks, and de Certeau begins his chapter with an acknowledgment and critique of this visual orientation. He situates the reader before a panorama of the city. The seduction of the panorama, he explains, is in the fantasy it constructs of an ability to grasp everything in one totalizing, all-encompassingly comprehensible, view. The panorama here exemplifies what de Certeau terms the scopic drive: a drive for legibility and disentanglement, the "lust to be a viewpoint and nothing more" (1988). From the panorama, we look without being observed, and we experience without being messily entangled in the physical, mental, political, and historical realities of the city. This is what, in another idiom, Donna Haraway calls the "god trick" (Haraway, 1988), the fantasy of a vantage point outside of a situated body. De Certeau proposes the act of walking as a way of countering such abstract ways of relating to the city. For de Certeau, when we walk, we experience ourselves as a part of the environment; we are not above it but within it.

\section{TURNING FROM EYE TO EAR}

However, l'd like to suggest that merely moving down from the panorama and into the streets is not an adequate intervention into the abstraction and alienation of advanced capitalism with which de Certeau is concerned. We must also turn from eye to ear. While the eye in Western cultural discourse and practice - as exemplified in de Certeau's panorama - represents control and objectification (a way of approaching the world as a resource to be exploited that is bound up in both patriarchy and settler-colonial capitalism), the ear can be figured as an ecologically responsive or feminist approach. Listening - inherently immersive, experiential and ever-present - enmeshes us in our surroundings. As artist and writer Salomé Voegelin (2013) argues, listening can be understood as "an act of engaging in the world." Of course, looking is an act of engaging in the world as well. As Vogelin (2018) explains, her critique of the visual is "not a critique of its object but of its practice." What Voegelin points to is that these two modes of engaging looking and listening - carry very different associations and values.

\subsection{Listening functions otherwise}

While binocular vision is optional and forwardfacing, listening functions otherwise. We don't have earlids that we can just close at will. Inescapable, sound surrounds us at all times and comes from all directions. We are situated, immersed, within sound. As vibration, sound literally touches us: our ears, our flesh, our bones. We experience this in our everyday: in bass felt in the belly, in loud sounds vibrating a windowpane, in the visceral response to a high-pitched squeak or fingers on a chalkboard. Most importantly, sound is coconstitutive, or interdependent. We are in the soundscape, yes, but we are also an active part of that soundscape. We are sounding bodies. As Douglas Kahn (2001) writes, "there is no visual equivalent to the utterance of the voice." The early Greeks thought that the eyes projected light beams, but our eyes do not, in fact, emit perceptible light. Our bodies, however, do create sounds; sounds that are heard both internally and from a distance, reconfigured and filtered by our immediate environment. Listening is bound up in its surroundings in a way that - when paid attention to - both models and invites responsiveness, responsibility, collaboration. As Voegelin (2016) puts it, "listening affords us a different sense of the world and of ourselves living in this world; it affords a different relationship to time and space, objects and subjects and the way we live among them." What is this different sense, this different relationship? To my mind, what is being argued for 
here is listening as a feminist, ecological, and relational practice.

\subsection{Deep Listening}

One exemplary relational feminist listener is Pauline Oliveros: the lesbian, pun-loving Texan who dedicated her life to listening. In the early 1970s, having decided that "we had heard from the men for long enough" (Oliveros, 1974), and wanting to find out what a deeply female, or feminist, music would sound like, Oliveros spent a year workshopping listening and sounding activities in an exclusively female-identified collective. The results of this research were published as a book of instruction scores, called "Sonic Meditations," that provide a template for community sounding that is profoundly participatory, inclusive, and nonhierarchical. These scores also formed the basis of what Oliveros would come to call Deep Listening, a practice of attending to one's sonic environment as fully and continually as possible. Attuned to both struggles for human liberation and the more-thanhuman world, Oliveros saw this mode of attention as promoting individual and collective emancipation, and, in her words, "communication among all forms of life" (1974).

\subsection{Soundwalking}

Around the time that Oliveros was developing her Sonic Meditations, Hildegard Westerkamp, then a research associate at the World Soundscape Project, was developing the practice of Soundwalking: artist-led public walks actively exploring the (usually urban) environment via sounds heard, out of a conviction that sonic information can uncover new and embodied insights about the ecological and social health of a place. While these walks are often led in silence, they are almost always a disruption of business as usual. Gathered in small or large groups, soundwalkers may walk in silence, they may activate the soundscape with their voices or found objects, or they may walk as ... slowly ... as ... possible. Importantly, these walks are typically followed by listening and sounding in the form of discourse, as participants are invited to reflect on and share their experiences.

\section{CONTEMPORARY PRACTICES}

Returning to my initial proposition of an alliance between walking, listening, and feminism, I'll turn now to the work of three contemporary artists influenced by both Deep Listening and Soundwalking practice: Suzanne Thorpe, Viv Corringham, and Amanda Gutierrez. While their work employs a range of different strategies for walking and listening, each relies on the embodied immersiveness of these practices to build connection to, and agency within, their environments.

\subsection{Environmental entanglements}

\subsubsection{Resonance and Resemblance}

Suzanne Thorpe's Resonance and Resemblance is a site-specific performance, or, as she terms it in reference to Oliveros' expanded listening practices, "sonic meditation" (Thorpe, 2017), for a 79-acre woodland garden in Garrison, NY (Figure 1). As conceived by Thorpe, Resonance a nd Resemblance prioritizes receiving rather than projecting sound. While the piece does features some sound projection - subtle, piercing tones composed to harmonize with resonant features of the environment, which Thorpe studied over a period of a year - this musical performance is set within a larger structure of participatory soundwalking and Oliveros-inspired listening scores that are designed to make the audience, in Thorpe's words, "more aware of their entanglements and interdependencies with each other and the environment" (2017).

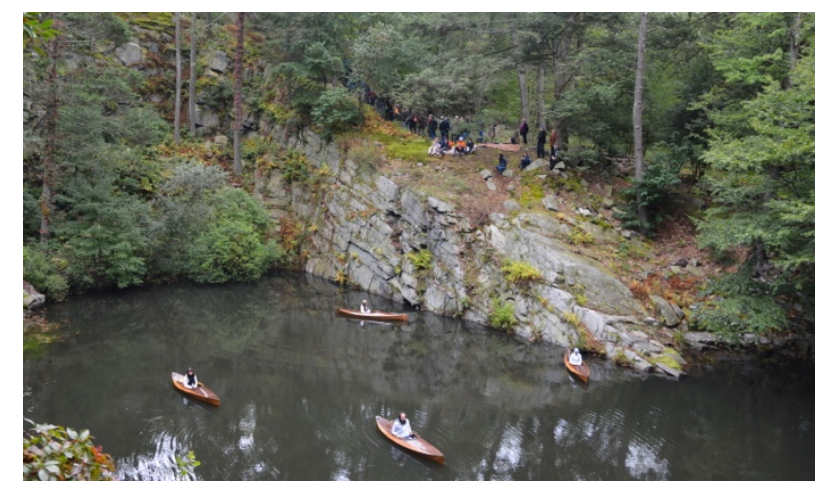

Figure 1: Resonance and Resemblance, Garrison, NY. Photo: Vivian Linares

Soundwalking was a core research methodology for Thorpe, a way of developing intimacy with the site over the many hours, days, weeks, and months of her compositional process. Wanting the audience to share in this experience of coming to know a site by moving through it, she invited guest artists, all trained in both Deep Listening and soundwalking practices (Michelle Nagai, Lisa B. Kelley, and myself), to lead the audience in soundwalks of their own design at the piece's opening. This was a "deliberate strategy of distributing power" (Thorpe, S. 2019, personal interview, 4 September), as she invited each soundwalk leader to bring their own expertise and agency to the piece. It was also a strategy to guide the listening audience into their own sense of listening agency. Here, listening and sounding agencies are distributed between multiple composers, performers, and the landscape itself.

\subsubsection{Shadowwalks}

Similarly attentive to listening as environmental entanglement is the work of Viv Corringham. In the ongoing project Shadowwalks (2003-present), 
Corringham asks individuals to take her on a personally meaningful walk, recording their conversations as they amble (Figure 2). For Corringham, joining together in a shared rhythm of walking generates a sense of intimacy and shared everyday experience with her collaborators (Corringham, V. 2019, personal interview, 9 September).

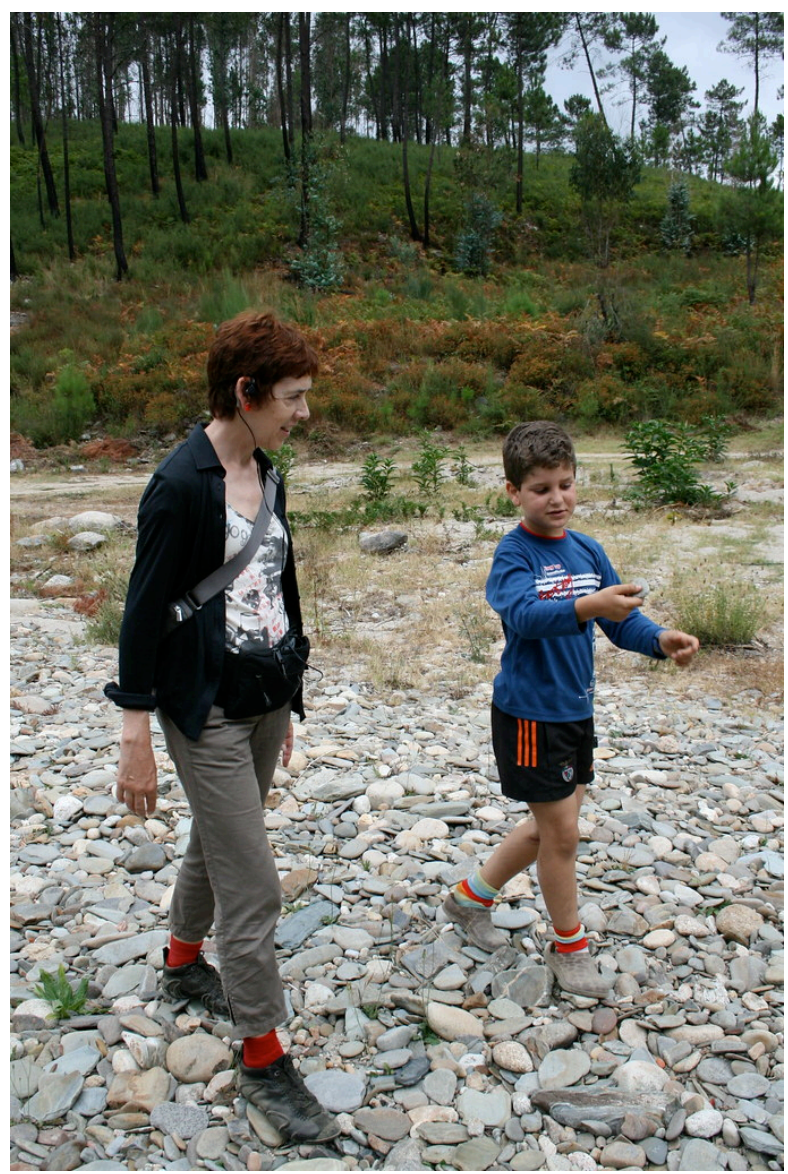

Figure 2: Viv $C$ orringham walking $w$ ith $c$ ollaborator. Nodar, Portugal. Photo: Binaural Media, Nodar

It is the guide's natural pace of walking that establishes the rhythm of their encounter, and Corringham will later strive to re-embody this rhythm while retreading their route. On this second, solo walk, she will sonify her memory of the first walk through vocal improvisation, listening for the sounds of the present moment, her remembered experience, and the resonances of her surroundings. Her final pieces - published on compact disc, via Soundcloud, and as an iPhone app - combine recordings of both walks. Here, Corringham engages in a responsive compositional practice that collaborates intimately with the walker, their route, and the changing acoustic environment.

\subsubsection{Listening as a shared orientation}

In these two works, Thorpe and Corringham decenter their own authorship to include the agency of human and more-than-human others. But unlike the dispassionate decentering of Cage's chance operations, they are sensitive to who they are sharing authorship with - whether the resonances of a quarry and the many-voiced landscape of which it is a part, or the daily path of a local walker. In the spirit of Oliveros' feminist music-making, these are compositional forms in which listening is foregrounded as a shared and non-hierarchical orientation.

\subsection{La flâneuse y la caminanta}

Amanda Gutierrez work engages with the history of the dérive and the figure of the flâneur in astute and political ways. Her projects situate listening squarely in the messy urban entanglements that de Certeau's panorama would distance us from, and highlight the ways in which what we hear and how we listen is shaped in unequal ways by how our bodies are coded in public space.

Gutierrez' Flâneuse>La caminanta documents individual soundwalks of female-identified participants, using video and virtual reality to communicate the stakes of participating in walking as a female subject (Figure 3 ).

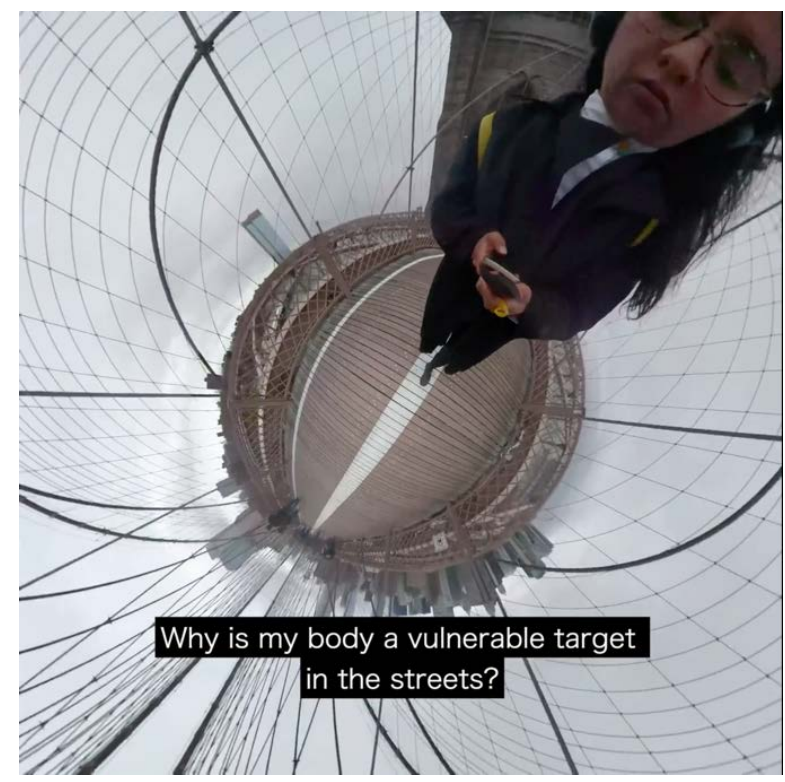

Figure 3: Flâneuse>La caminanta, video still

Equally powerful is the Brooklyn League of Women Walkers, a collaboration between Gutierrez and Walis Johnson, that provides a context for the investigation and re-imagination of the daily walking experiences of women of color. Bringing attention to the streets as sites of intersectional difference in need of reclaiming, the methodology for these walks includes identifying what being vulnerable or empowered in public space means to each participant, tuning the ears though Deep Listening exercises adopted from Pauline Oliveros, and then walking as a group to public locations that highlight the issues discussed. After each walk, participants create subjective maps of their experience (Figure 4) and collectively explore how existing sites might be re-imagined: a pedestrian walkway here, a bike 
path there, a community gathering space, et cetera (Gutierrez, 2019).

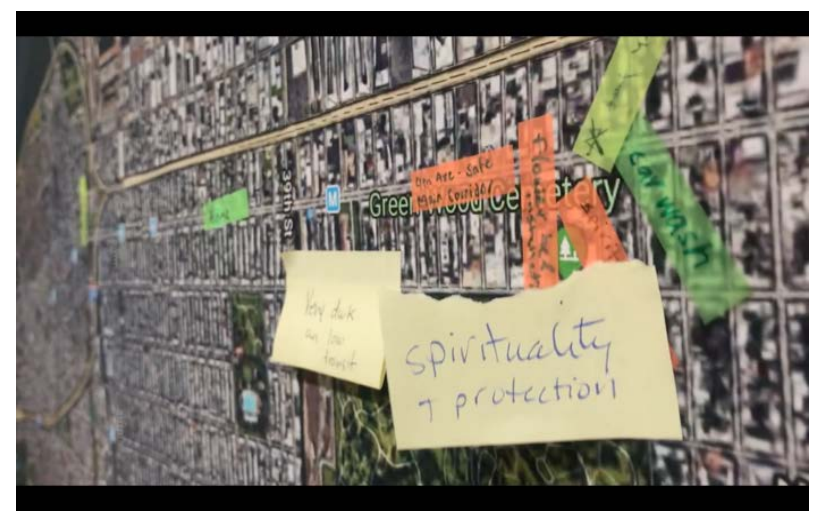

Figure 4: Documentation from the B rooklyn L eague of Women Walkers. Video still: Amanda Gutierrez

In this work, a focus on sound and listening opens into community dialog, do-it-yourself cartography, and oral history, an approach also equally evidenced in Gutierrez' series of soundwalks in gentrifying areas (Chicago, New York, and Girona, Spain). In these soundwalks, Gutierrez leads participants in what she terms "derivas sonoras", or sonic dérives (Gutierrez, n.d.). Here, Debord's psychogeographic flows of attraction are attuned to acoustic geographies, bringing attention to cultural information - from language diversity to flight patterns - that might be otherwise overlooked. The resulting final forms of the projects span interviews, field recordings and exercises in guerilla urban planning (in addition to the photography, video, and virtual reality pieces that are presented in gallery spaces).

It is this collective investigation and re-imagination that I find most inspiring in Gutierrez' work. Here, an experience of Deep Listening can open into an insight that can find its way into a conversation, onto a sticky-note on a map, into the ear of an urban planner, and onwards, into a world that is in need not only of new ways of being, but of new ways of doing that emerge from those new ways of being. In Gutierrez' projects this political dimension becomes tangible, as she invites audiences to engage critically with their surroundings, with the goal of developing spaces of collaboration and creation for all, but especially for those whose bodies are most vulnerable and whose voices are most silenced in public space and public discourse.

\section{WHAT IS FLÂNEUSERIE SONORE?}

To return to the question with which I began: What is feminist soundwalking, or flâneuserie sonore? It is my contention, and the contention of this paper, that practices of listening and walking can seed new relationships to the world around us. Feminist soundwalking moves us from eye to ear, from distant panorama to vibrating immediacy. Thorpe's distributed listening agency, Corringham's responsive walks, and Gutierrez' ear-oriented socio-political intervention all invite their audiences to both feel into, and reflect critically on, their interrelationships with the world around them. This is at the core of a feminist approach to soundwalking, one that, in the terms of feminist visual cultural theorist Irit Rogoff, takes criticality a mode of situated entanglement - as its ethical given. At a historical juncture where ecological and political crises abound, they offer ways to connect to who and where we are, to feel our enmeshment in the worlds around us, and to find new ways to respond.

\section{REFERENCES}

Balzac, H. (1886) The Works of Honore de Balzac. Translated by K. P. Wormeley, 2010. Project Gutenberg. http://www.gutenberg.org/ (retrieved 14 September 2019).

Debord, G. (1956) Theory of the Dérive. Situationist International Online. Translated by Ken Knabb. Bureau of Public Secrets. https://www.cddc.vt.edu/sionline/si/theory.html (retrieved 14 September 2019).

De Certeau, M. (1980) The $P$ ractice of E veryday Life. Translated by S. Rendall, 1988. Oakland, CA: University of California Press.

Elkin, L. (2017a) Flâneuse: Women Walk the City in Paris, New York, Tokyo, Venice, and London. New York: Farrar, Straus and Giroux.

Elkin, L. (2017b) The $C$ ase for the F lâneuse (A. Adhikari, Interviewer). The Atlantic. https://www.theatlantic.com/ (retrieved 14 September 2019).

Fournel, V. (1867) Ce qu'on voit dans les rues de Paris. Paris: A. Delahays.

Gutierrez, A. (2016) Derivas de Girona. Tumblr. https://derivasgirona.tumblr.com/page/2 (retrieved 14 September 2019).

Gutierrez, A. (2019) Flâneuse>La c aminanta. Sounding Out!. Available from: https://soundstudiesblog.com/ (14 September 2019).

Kahn, D. (2001) Noise, Water, Meat: A History of Sound in the Arts. Cambridge, MA: The MIT Press.

Oliveros, P. (1974) Sonic Meditations. Sharon, VT: Smith Publications.

Kahn, D. (2001) Noise, Water, Meat: A History of Sound in the Arts. Cambridge, MA: The MIT Press.

Rogoff, I. (2003) From Criticism t o C ritique to Criticality. transversal / EIPCP multilingual 
webjournal. Available from: http://eipcp.net/transversal/0806/rogoff1/en.html (14 September 2019).

Thorpe, S. (n.d.) Resonance-Resembance. Artist website. https://www.suzannethorpe.com/ (14 September 2019).

Voegelin, S. (2013) Listening to Noise and Silence: Towards a Philosophy of Sound Art. London: Bloomsbury Academic.).

Voegelin, S. (2014) Sonic Possible Worlds: Hearing the $C$ ontinuum of Sound. London: Bloomsbury Academic. 